\title{
Bio-coal briquettes made from South Sumatera low rank coal and palm shell charcoal for using in small industries
}

\author{
Riman Sipahutar ${ }^{1, *}$, Irwin Bizzy ${ }^{1}$, Muhammad Faizal ${ }^{2}$, Olistiyo Maussa $^{1}$ \\ ${ }^{1}$ Mechanical Engineering Department, Engineering Faculty, Sriwijaya University, 30139 Palembang, Indonesia \\ ${ }^{2}$ Chemical Engineering Department, Engineering Faculty, Sriwijaya University, 30139 Palembang, Indonesia
}

\begin{abstract}
The objective of this study is to blend the South Sumatera low rank coal and palm shell charcoal for producing bio-coal briquettes which have better fuel properties. The experimental study for making biocoal briquettes was carried out to examine the effect of raw material composition and binder type on the quality of the briquettes produced. A screw conveyor machine equipped with a three blade stirred and designed with the length of $40 \mathrm{~cm}$, mixing process diameter of $10 \mathrm{~cm}$ and the capacity of $2 \mathrm{~kg}$ bio-coal briquettes per hour was used to produce bio-coal briquettes ready to use in small industries. Proxymate analyses of the South Sumatera low rank coal, palm shell charcoals and bio-coal briquettes were conducted in accordance with the American Society of Testings and Materials (ASTM) standards and the calorific value was determined by using a Bomb calorimeter. The experimental results showed that the calorific value of bio-coal briquette was greatly influenced by the raw material composition and the binder type. The highest calorific value was $6438(\mathrm{cal} / \mathrm{g})$ at the sampel of SSC65-PSC20-B15(2).
\end{abstract}

\section{Introduction}

The government of Indonesia has already proclaimed the increased use of coal for domestic interest and the decreased export of coal through a National Energy Policy. Coals of different varieties and their characterization are very vital in deciding their suitable applications [1]. The use of energy derived from coal will be incrased approximately $33 \%$ of Indonesia's total energy by 2025 . South Sumatera Province as one of the producers of coal in Indonesia has the potential to support that national policy. Most coal reserves owned by the provincial government of South Sumatera is low-quality brown (lignite) or sub-bituminous coals having calorific value of 5.000-6.500 kcal $/ \mathrm{kg}$ but low sulphur and ash contents. Based on the Indonesian National Standard (SNI 13-60111999), South Sumatera low rank coals can be categorized as brown coals which are soft, easily crushed, and having high moisture content (10-70\%). It has been proved that blending coal with biomass give rise to briquettes which have better fuel properties and less harmful emissions compared to raw coal briquettes [2]. In addition, lignite tends to ignite spontaneously due to it's high moisture content and porous structure [3].

Currently, the prices of fuel oil and LPG for household and home industry are still quite high. The use of bio-coal briquettes as an alternative fuel has been proclaimed by the Indonesian government but still faces many problems such as poor quality of briquettes and combustion equipments as well as high levels of pollution produced.

Low rank coals usually contain a high amount of moisture, rendering low energy output and low fuel efficiency compared to high-rank coals [4,5]. The use of low rank coal as the primary raw material in the manufacture of bio-coal briquettes is not ready-made, especially with regard to the composition and type of binder required, the size of coal particles and the necessary pressure on the briquetting process. It is necassary to blend the coal for maximazing the efficiency and avoiding environmental hazards especially when coals are highly used for energy purposes [6]. The raw materials in the manufacture of bio-coal briquettes were South Sumatera low rank coals and palm shell charcoals existing in numerous amounts in the province of South Sumatera. Binder in briquetting process was a solution consisting of starch powder, water and caustic soda.

\section{Experimental details}

\subsection{Sources and preparation of materials}

South Sumatera low rank coal samples were collected from coal mine site of PT Bukit Asam (Persero), Tbk located in Tanjung Enim, South Sumatera - Indonesia.

*Corresponding author: riman_sipahutar@yahoo.com 
The coal samples are labelled as SSC. The palm shell charcoals were collected from PT Global Deorub Industry located at J1. Pangeran Sido Ing Kenayan No. 88, Kelurahan Karang Anyar, Palembang, South Sumatera Indonesia. The materials of binder for briquetting were starch powder and caustic soda purchased in open market. The coals and palm shell charcoals were dried and pulverized before sieving to 100 mesh size.

\subsection{Proximate analyses and calorific value of samples}

Proximate analyses of the South Sumatera low rank coals, palm shell charcoals and bio-coal briquettes were conducted in accordance with American Society of Testing and Materials (ASTM) and the calorific value was determined by using a Bomb Calorimeter.

\subsubsection{Moisture content}

The moisture content of coals, charcoals and biocoal briquettes was determined based on American Society for Testing and Materials Standards [7]. Each sample (1 g) was weighed in a crucible that has been weighed previously. Next, the crucible plus sample was placed in a cold muffle furnace and heated to $104^{\circ} \mathrm{C}$ for one hour to evaporate the moisture. The heated crucible was then cooled in a desiccator. The cold crucible was reweighed to get the percentage of weight loss as the sample percentage of moisture content.

\subsubsection{Volatile Matter}

The volatile matter of coals, charcoals and biocoal briquettes was determined based on ISO-562:2019 (e). Each moisture free sample $(1 \mathrm{~g})$ was weighed in a crucible covered with lid. Next, the lid covered crucible and its content was placed in a muffle furnace and heated to $925^{\circ} \mathrm{C}$. It was removed after staying exactly 7 minutes in the hot zone of the furnace just before attaining the ignition temperature and was then cooled in a desiccator. The cold crucible with its content was reweighed to get the percentage of weight loss as the sample percentage of volatile matter.

\subsubsection{Ash}

The ash content of coals, charcoals and biocoal briquettes was determined based on American Society for Testings and Materials Standards [8]. Each moisture free sample $(1 \mathrm{~g})$ was weighed in a clean crucible. Next, the uncovered crucible with its content was placed in a cold muffle furnace and heated gradually so that the temperature increased to $500^{\circ} \mathrm{C}$ in one our and $750^{\circ} \mathrm{C}$ in two hours. The hot crucible was then cooled and covered in a desiccator. The cold crucible with its content was reweighed to get the percentage of remaining weight as the sample percentage of ash content.

\subsubsection{Fixed Carbon}

The fixed carbon of coals, charcoals and biocoal briquettes was determined based on American Society for
Testings and Materials Standards [9] The fixed carbon content of coal was determined by substracting the percentages of moisture, volatile matter and ash from the original mass of the coal sample.. It can be written as follows:

$$
F C=100-(M O S+V M+A)
$$

where $F C$ is the percentage of fixed carbon, MOS is the percentage of moisture content, $V M$ is the percentage of volatile matter and $A$ is the percentage of ash in the sample analized.

\subsubsection{Determination of calorific value of samples}

The calorific value of the samples was determined based on American Society for Testing and Materials standards [10]. The Ballistic Bomb Calorimeter used was fist calibrated using a standard sample of benzoic acid whose known calorific value is $6.32 \mathrm{kcal} / \mathrm{g}$. A small mass quantity $(0.5 \mathrm{~g})$ of different samples were placed in a crucible. The body of bomb calorimeter was screwed in its position and the thermocouple wire was plugged into it. The pressure release valve was closed and oxygen was allowed to enter the bomb until the pressure rose to 25 bars. Then, the firing knob was pressed and released to fire the bomb. Heat was released and the maximum deflection of galvanometer scale was recorded. The maximum deflection of galvanometer scale was then converted to energy value of the sample material by comparing the rise in galvanometer deflection with that obtained when a sample of known calorific value of benzoic acid is combusted as shown in equation below: Heat released from sample,

$$
Q=\frac{\text { Galvanometer Deflection } \mathrm{x} \text { Calibration constant }}{\text { Mass of sample }}
$$

The above equation is equal to:

$$
Q=\frac{\left(\theta_{3}-\theta_{1}\right) \times \gamma}{Z} \mathrm{kcal} / \mathrm{kg}
$$

where $\theta_{3}$ is the galvanometer deflection with sample, $\theta_{1}$ is the galvanometer deflection without sample, $Z$ is the mass of sample $=z g$, and $\gamma$ is the calibration constant.

The complete experiments were repeated for all different samples of South Sumatera low rank coals, palm shell charcoals and bio-coal briquettes.

\subsection{Preparation of the biocoal briquette samples}

The South Sumatera low rank coal and palm shell charcoal samples were ground before sieving to 100 mesh size. Then, the samples were labelled as SSC and PSC, respectively. The starch powder, pure water and caustic soda liquid were also prepared as binder materials and labelled as SP, WTR and CSL, respectively. The materials of bio-coal briquettes consist of the South Sumatera low rank coals, the palm shell charcoals, and the binders. There are two types of binders used in this research, i.e. the combination of starch powder and water with the mass ratio of $1: 2$, and the combination of starch powder, water 
and caustic soda liquid with the mass ratio of $1: 1: 1$. The South Sumatera low rank coals (labelled as SSC), the palm shell charcoals (labelled as PSC) and the binders (labelled as B) were blended at various mixing proportions of $45: 40: 15(1), 55: 30: 15(1), 65: 20$ : $15(1), 45: 40: 15(2), 55: 30: 15(2)$, and $65: 20: 15(2)$. The proportion of $15(1)$ means that the mass percentage of the binder is $15 \%$ with the composition of SP and WTR at the mass ratio of $1: 2$ (labelled as B15(1)). The proportion of 15(2) means that the mass percentage of the binder is $15 \%$ with the composition of SP, WTR and CSL at the mass ratio of $1: 1: 1$ (labelled as B15(2)). The samples were weighed using a digital weighing balance with maximum load of $500 \mathrm{~g}$ and accuracy of $0.01 \mathrm{~g}$. The various concentrations were loaded into the mixing compartment of a screw conveyor machine.

\subsection{Screw conveyor machine}

The screw conveyor machine designed and manufactured in this research can be seen in the Fig. 1. The machine was equipped with a stirrer for mixing the briquitting materials. The compaction process to produce biocoal briquettes occurs due to the movement of conveyor screw pressing briquetting materials through a channel with a smaller cross sectional area. The machine was designed with the length of $40 \mathrm{~cm}$, the diameter of $10 \mathrm{~cm}$, and the capacity of $2 \mathrm{~kg}$ briquettes per hour. Before running the machine, the components of briquetting process should be prepared in accordance with the composition expected. The raw materials of South Sumatera low rank coal and palm shell charcoal should be ground to the size of 100 mesh and the bonding solution should also be prepared as much as $15 \%$ (by weight) of the briquetting mixture.

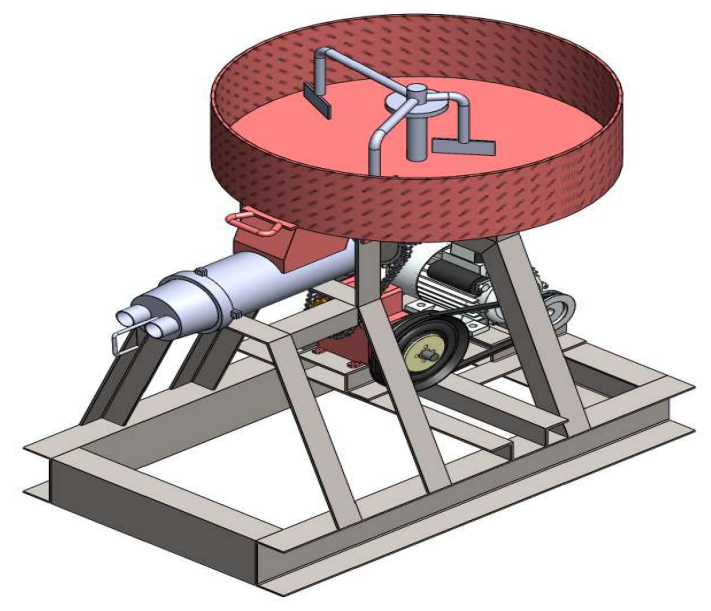

Fig. 1. The screw conveyor machine

\section{Results and discussions}

\subsection{Results}

Several activities have been conducted in the production of bio-coal briquettes including the design and manufacture of a machine to form the bio-coal briquettes and testing the characteristics of the briquettes produced. The mixing container has a diameter of $40 \mathrm{~cm}$ and a height of $8 \mathrm{~cm}$ and it is also equipped with three stirring rods having different lengths. The proximate analyses of raw materials of South Sumatera low rank coals and palm shell charcoals are presented in Table 1.

Table 1. Proximate analyses of raw materials

\begin{tabular}{|c|c|c|c|c|c|c|}
\hline No. & Samples & $\begin{array}{c}\text { Inherent } \\
\text { Moisture } \\
(\%)\end{array}$ & $\begin{array}{c}\text { Ash } \\
(\%)\end{array}$ & $\begin{array}{c}\text { Volatile } \\
\text { Matter } \\
(\%)\end{array}$ & $\begin{array}{c}\text { Fixed } \\
\text { Carbon } \\
(\%)\end{array}$ & $\begin{array}{c}\text { Calorific } \\
\text { Value } \\
(\mathrm{cal} / \mathrm{g})\end{array}$ \\
\hline 1. & SSC & 7.81 & 3.76 & 42.60 & 45.83 & 6299 \\
\hline 2. & PSC & 5.41 & 15.25 & 36.07 & 43.27 & 5550 \\
\hline
\end{tabular}

The proximate analyses of various biocoal briquettes can be seen in Table II.

Table 2. Proximate analyses of samples

\begin{tabular}{|c|c|c|c|c|c|c|}
\hline No. & Samples & $\begin{array}{c}\text { Inherent } \\
\text { Moisture } \\
(\%)\end{array}$ & $\begin{array}{c}\text { Ash } \\
(\%)\end{array}$ & $\begin{array}{c}\text { Volatile } \\
\text { Matter } \\
(\%)\end{array}$ & $\begin{array}{c}\text { Fixed } \\
\text { Carbon } \\
(\%)\end{array}$ & $\begin{array}{c}\text { Calorific } \\
\text { Value } \\
(\mathrm{cal} / \mathrm{g})\end{array}$ \\
\hline $\begin{array}{c}\text { SSC45- } \\
\text { PSC40- } \\
\text { B15(1) }\end{array}$ & 2.93 & 6.95 & 44.79 & 45.33 & 6073 \\
\hline 2. & $\begin{array}{c}\text { SSC55- } \\
\text { PSC30- } \\
\text { B15(1) }\end{array}$ & 3.21 & 6.02 & 45.20 & 45.57 & 6121 \\
\hline 3. & $\begin{array}{c}\text { SSC65- } \\
\text { PSC20- } \\
\text { B15(1) }\end{array}$ & 3.26 & 5.36 & 45.59 & 45.79 & 6139 \\
\hline 4. & $\begin{array}{c}\text { SSC45- } \\
\text { PSC40- } \\
\text { B15(2) }\end{array}$ & 2.50 & 5.55 & 45.35 & 46.60 & 6223 \\
\hline 5. & $\begin{array}{c}\text { SSC55- } \\
\text { PSC30- } \\
\text { B15(2) }\end{array}$ & 3.48 & 4.24 & 45.56 & 46.72 & 6400 \\
\hline 6. & $\begin{array}{c}\text { SSC65- } \\
\text { PSC20- } \\
\text { B15(2) }\end{array}$ & 3.68 & 3.73 & 45.77 & 46.82 & 6438 \\
\hline
\end{tabular}

\subsection{Discussions}

\subsubsection{Effect of blending composition on calorific value (cal/g)}

Figure 2 shows the effect of blending composition on calorific value $(\mathrm{cal} / \mathrm{g})$ at No. 1 binder type. For each blending composition, the percentage of binder was $15 \%$.

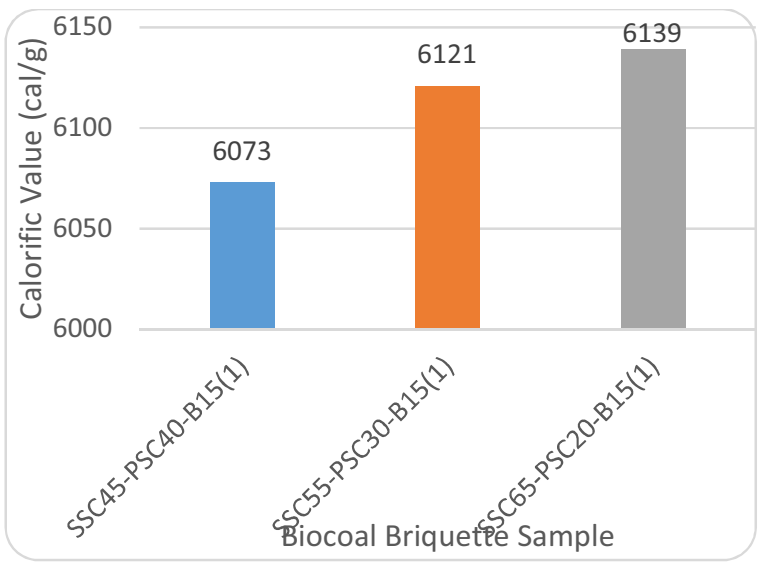

Fig.2. The effect of blending composition on calorific value (cal/g) at No. 1 binder type 
The bonding solution was made from a mixture of starch and water with a mass ratio of $1: 2$. It was observed that the bio-coal briquette of SSC65-PSC20-B15(1) has the highest calorific value of $6139(\mathrm{cal} / \mathrm{g})$ and the bio-coal briquette of SSC45-PSC40-B15(1) has the lowest calorific value of 6073 (cal/g). The calorific value of biocoal briquette increased from $6073(\mathrm{cal} / \mathrm{g})$ to 6139 (cal/g) with decreasing proportion of palm shell charcoal from $40 \%$ to $20 \%$ (by weight). The increase of calorific value may due to the addition of coal material (from $45 \%$ to $65 \%$ ) which has higher calorific value compared to palm shell charcoal material.

Figure 3 below shows the effect of blending composition on calorific value (cal/g) at No. 2 binder type. For each blending composition, the percentage of binder was fixed to $15 \%$ (by weight).

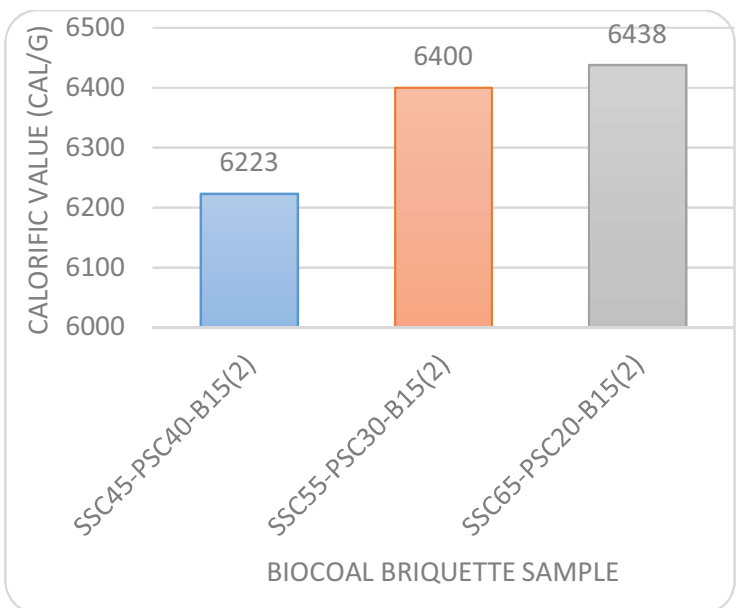

Fig.3. The effect of blending composition on calorific value $(\mathrm{MJ} / \mathrm{kg})$ at No. 2 binder type

It was observed that the bio-coal briquette of SSC65PSC20-B15(2) has the highest calorific value of 6438 (cal/g) and the bio-coal briquette of SSC45-PSC40$\mathrm{B} 15(2)$ has the lowest calorific value of $6223(\mathrm{cal} / \mathrm{g})$. The calorific values of bio-coal briquettes increased from $6223(\mathrm{cal} / \mathrm{g})$ to $6438(\mathrm{cal} / \mathrm{g})$ with decreasing proportion of palm shell charcoal from $40 \%$ to $20 \%$ (by weight). In addition, the increase of calorific value may be due to the addition of coal material (from $45 \%$ to $65 \%$ ) which has higher calorific value compared to palm shell charcoal material.

\subsubsection{Effect of blending composition on proxymate analyses}

The proxymate analyses of samples were conducted to determine the percentages of fixed cabon, volatile matter, ash and moisture contents. Figure 4 shows the effect of blending composition on proxymate analyses at No. 1 binder type.

It was observed that the bio-coal briquette of SSC45PSC40-B15(1) has the lowest fixed carbon of $45.33 \%$ and SSC65-PSC20-B15(1) has the highest fixed carbon of $45.79 \%$. The percentage of fixed carbon increased from 45.33 to $45.79 \%$ with increasing proportion of coal from 45 to $65 \%$ (by weight). The increased percentage of fixed carbon may be due to the addition of coal material which has higher fixed carbon compared to palm shell charcoal material. Fixed carbon is a measure of the solid combustible material in solid fuel after the expulsion of volatile matter.

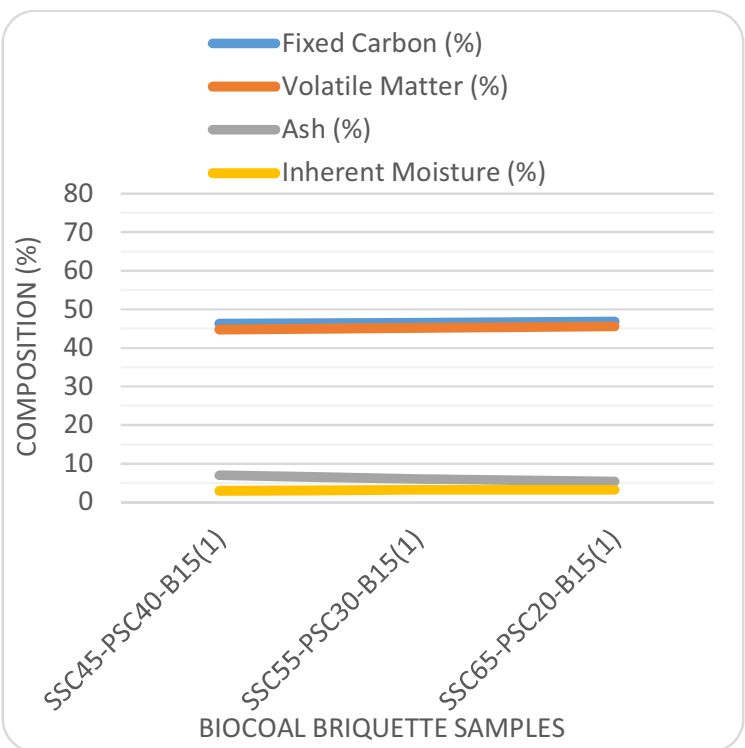

Fig.4. The effect of blending composition on proximate analyses at No.1 binder type

It was observed that the bio-coal briquette of SSC45PSC40-B15(1) has the lowest fixed carbon of $45.33 \%$ and SSC65-PSC20-B15(1) has the highest fixed carbon of $45.79 \%$. The percentage of fixed carbon increased from 45.33 to $45.79 \%$ with increasing proportion of coal from 45 to $65 \%$ (by weight). The increased percentage of fixed carbon may be due to the addition of coal material which has higher fixed carbon compared to palm shell charcoal material. Fixed carbon is a measure of the solid combustible material in solid fuel after the expulsion of volatile matter.

Fig. 4 also shows that the sample of SSC45-PSC40$\mathrm{B} 15(1)$ has the lowest volatile matter of $44.79 \%$ and the sample of SSC65-PSC20-B15(1) has the highest volatile matter of $45.59 \%$ bound with the binder type of No.1. The volatile matter increased with increasing the proportion of coal material from 45 to $65 \%$.. The increase in volatile matter may be due to the addition of coal material which is higher in volatile matter compared to palm shell charcoal.

In the case of inherent mointure content, it was observed that the sample of SSC45-PSC40-B15(1) has the lowest moisture content of $2.93 \%$ and SSC65-PSC20$\mathrm{B} 15$ (1) has the highest moisture content of $3.26 \%$ (Fig. 4). The percentage of inherent moisture increased with increasing proportion of coal from 45 to $60 \%$ (by weight). The increased percentage of moisture content may be due to the addition of coal material which has higher moisture content compared to palm shell charcoal material. Moisture content is a undesirable element because it reduces calorific value and its weight adds to the transportation cost of solid fuel. Nevertheless, the percentages of moisture in all bio-coal briquette are low enough not to have seriously negative impact on the combustibility of the samples when used for household industries.

Fig.5 below shows that the bio-coal briquette of 
SSC45-PSC40-B15(2) has the highest fixed carbon of $49.81 \%$ and SSC65-PSC20-B15(2) has the lowest fixed carbon of $46.50 \%$.

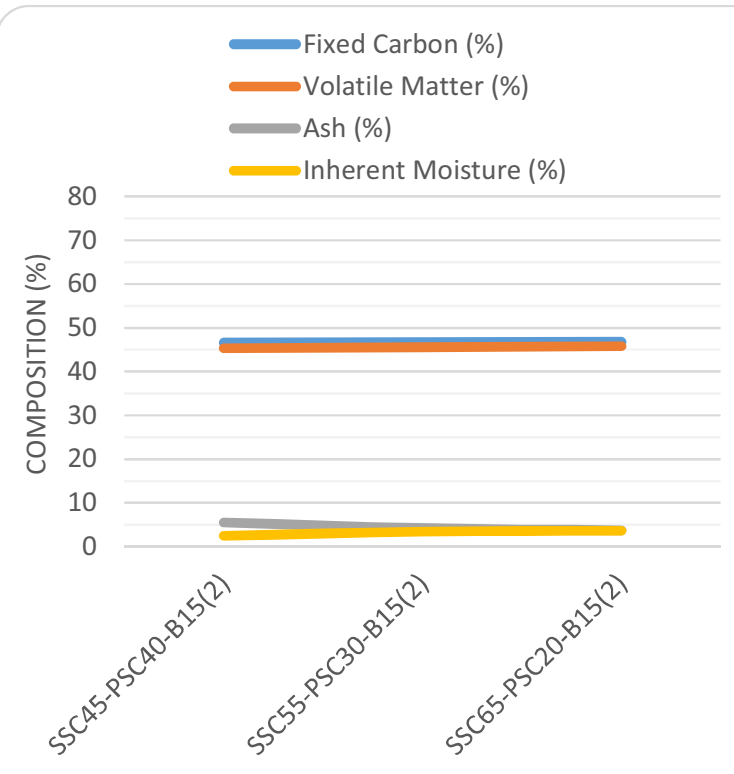

BIOCOAL BRIQUETTE SAMPLES

Fig.5. The effect of blending composition on proximate analyses at No. 2 binder type

The percentage of fixed carbon at No.2 binder type increased from 46.60 to $49.82 \%$ with increasing proportion of coal from 45 to $65 \%$ (by weight). The increased percentage of fixed carbon may be due to the addition of coal material which has higher fixed carbon compared to palm shell charcoal material. Fixed carbon is a measure of the solid combustible material in solid fuel after the expulsion of volatile matter. The percentages of fixed carbon of all the bio-coal briquettes bonding with No.2 binder type are higher than of coal material which makes them better as a solid fuel in comparison to South Sumatera low rank coals.

Fig. 5 also shows that the sample of SSC45-PSC40$\mathrm{B} 15(2)$ has the lowest volatile matter of $45.35 \%$ and the sample of SSC65-PSC20-B15(1) has the highest volatile matter of $45.77 \%$ bound with the No. 1 binder type. The volatile matter increased with increasing the proportion of coal material from 45 to $65 \%$. The increase in volatile matter may be due to the addition of coal material which is higher in volatile matter compared to palm shell charcoal. The quantity of volatile matter determine whether the briquette will burn with good flame and whether it will produce smoke. The briquette having higher volatile matter will produce higher level of smoke.

In the case of inherent mointure content, it was observed that the sample of SSC45-PSC40-B15(2) has the lowest moisture content of $2.50 \%$ and SSC65-PSC20$\mathrm{B} 15(2)$ has the highest moisture content of 3.68\% (Fig. 5). The percentage of inherent moisture increased with increasing proportion of coal from 45 to $65 \%$ (by weight). The increased percentage of moisture content may be due to the addition of coal material which has higher moisture content compared to palm shell charcoal material. Moisture content is a undesirable element because it reduces calorific value and its weight adds to the transportation cost of solid fuel. Nevertheless, the percentages of moisture in all biocoal briquette are low enough (less than 5\%) not to have seriously negative impact on the combustibility of the briquette when used for household industries.

\subsubsection{Effect of binde type on calorific value}

The following Fig. 6 shows the effect of binder type on calorific value (cal/g) at various compositions of bio-coal briquettes. For each blending composition, the percentage of binder solution was $15 \%$. The bonding solution of No. 1 binder type was made from a mixture of starch (tapioca flour) and water with a mass ratio of $1: 2$. For No. 2 binder type, the binder solution consists of starch, water and caustic soda with the mass ratio of $1: 1: 1$. It was obvious that the use of caustic soda as part of the binder solution resulted on the increase of calorific value for various compositions of biocoal briquettes. The sample of SSC45-PSC40-B15(2) has the higher calorific value of $6223(\mathrm{cal} / \mathrm{g})$ compared to the sample of SSC45-PSC40B15(1) having calorific value of $6073(\mathrm{cal} / \mathrm{g})$. The increase in calorific value was $2.47 \%$. The highest calorific value was $6438(\mathrm{cal} / \mathrm{g})$ at the sample of SSC65PSC20-B15(2) with the increased percentage of $4.87 \%$ compared to the sample of SSC65-PSC20-B15(1).

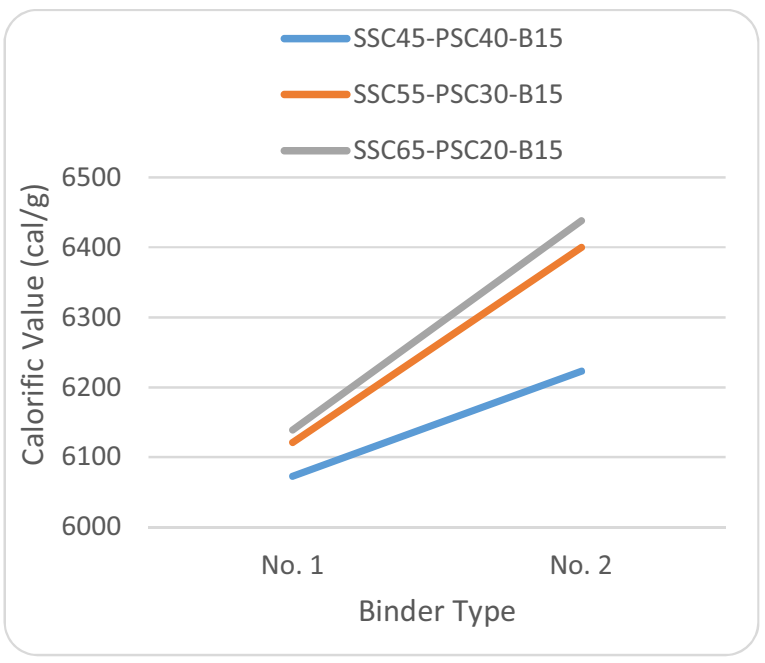

Fig.6. The effect of binder type on calorific value of briquette (cal/g) at various compositions

\section{Conclusions}

The calorific value of the bio-coal briquettes was greatly influenced by the raw material composition and the binder type. The calorific value increased with increasing proportion of coal in the biocoal briquettes.

The effect of binder type on calorific value was also studied, showing that the briquettes bound with No.2 binder type have higher calorific value campared to that bound with No.1 binder type at the same raw material composition.

The highest calorific value of bio-coal briquettes was 
$6438(\mathrm{cal} / \mathrm{g})$ at the composition of South Sumatera low rank coal of $65 \%$, palm shell charcoal of $20 \%$ and No. 2 binder type of $15 \%$.

The authors would like to express our sincere and deepest gratitude to Anis Saggaff, the rector of Sriwijaya University, for his support and motivation to present this paper on Sriwijaya International Conference on Engineering, Science and Technology (SICEST) 2016. The authors would also like to thank and express our deepest respect to Subriyer Nasir, the dean of the Faculty of Engineering, Sriwijaya University, for his support and strong encouragement to participate on this SICEST, 2016. Great thanks also submitted to the laboratory officers of Mining and Energy Agency of South Sumatera Province, Indonesia, for providing proximate analyses of the samples.

\section{References}

1. J.O. Adekunle, J.S. Ibrahim, and E.I. Kucha, BJAST 7(1), (2015)

2. H. Kim, G. Lu, T. Li and M. Sadakata, Environ.Sci. Technol. 36(7): (2002)
3. K. Muthusamy, V.M. Kuma Joshua, C.S. Hoe and L.Y. Ngo David, Drying Technology, 25 (2007)

4. Z. Rao, Y. Zhao, C. Huang, C. Duan and J. He, Prog. in Energy Combust. Sci., 46 (2015)

5. H. Osman, S.V. Jangam, J.D. Lease and A.S. Mujumdar, Drying Technol., 29 (2011)

6. T.U. Onuegbu, N.O. Ilochi, I.M. Ogbu, F.O. Obumselu, and I. Okafor, Curr. Res. Chem., 4(4): (2012)

7. ASTM D3173, Standard Test Method for Moisture in the Analysis Sample of Coal and Coke, (1987).

8. ASTM D3174-11, Standard Test Method for Ash in the Analysis Sample of Coal and Coke from Coal, ASTM International, West Conshohocken, PA, (2011).

9. ASTM D5142-09, Standard Test Methods for Proximate Analysis of the Analysis Sample of Coal and Coke by Instrumental Procedures, ASTM International, West Conshohocken, PA (2009).

10. ASTM D5865-11a, Standard Test Method for Gross Calorific Value of Coal and Coke, ASTM International, West Conshohocken, PA (2011). 